\title{
Les jarres à vin de Géorgie (Caucase)
}

Note de recherche

\section{Pascal Reigniez}

\section{OpenEdition}

Journals

Édition électronique

URL : https://journals.openedition.org/tc/360

DOI : $10.4000 /$ tc. 360

ISSN : 1952-420X

Éditeur

Éditions de l'EHESS

\section{Édition imprimée}

Date de publication : 1 juillet 1999

ISSN : 0248-6016

Référence électronique

Pascal Reigniez, «Les jarres à vin de Géorgie (Caucase) », Techniques \& Culture [En ligne], 33 | 1999,

mis en ligne le 26 octobre 2005, consulté le 29 septembre 2022. URL : http://journals.openedition.org/ tc/360 ; DOI : https://doi.org/10.4000/tc.360

Ce document a été généré automatiquement le 29 septembre 2022.

Tous droits réservés 


\section{Les jarres à vin de Géorgie (Caucase)}

Note de recherche

Pascal Reigniez 